\title{
PELAKSANAAN KEBIJAKAN SERTIFIKASI GURU DALAM MENINGKATKAN PROFESIONALISME GURU DI KALIMANTAN TIMUR (STUDI KASUS DI KOTA SAMARINDA, KOTA BALIKPAPAN, KABUPATEN KUTAI KARTANEGARA DAN KABUPATEN KUTAI TIMUR)
}

\section{(IMPLEMENTATION OF TEACHER CERTIFICATION POLICY TO IMPROVE TEACHER'S PROFESSIONALISM IN KALTIM (CASE STUDY IN SAMARINDA, BALIKPAPAN, KUTAI KARTANEGARA DAN KUTAI TIMUR))}

\author{
Ratih Fenty Anggriani Bintoro, Yuli Fitrianto \\ Badan Penelitian dan Pengembangan Provinsi Kalimantan Timur \\ Jalan M.T. Haryono Rawa Indah Samarinda 75124 \\ Email : fentybintoro@gmail.com
}

Diterima : 11 Desember 2019; Direvisi : 23 Desember 2019; Disetujui :27 Desember 2019

\begin{abstract}
ABSTRAK
Penelitian ini bertujuan untuk menggambarkan keterkaitan sertifikasi guru dengan profesionalisme guru di Kaltim (Kota Samarinda, Kota Balikpapan, Kab. Kutai Kartanegara dan Kutai Timur). Jenis penelitian ini menggunakan penelitian kualitatif melalui metode penjelasan (explanatory). Teknik pengumpulan data dilakukan melalui FGD dan wawancara dengan Dinas Pendidikan, Pengawas Sekolah, Kepala Sekolah dan Guru juga didukung oleh studi literatur yang berhubungan dengan kebijakan sertifikasi guru. Hasil penelitian menunjukkan bahwa profesionalisme guru tersertifikasi di Kalimantan Timur pada umumnya telah cukup baik. Guru telah memenuhi standar kerja yang ditetapkan, namun standar kinerja yang dipenuhi oleh guru cenderung hanya bersifat pemenuhan kewajiban dan belum merupakan perwujudan dari budaya kerja profesional. Faktor-faktor pendorong munculnya kinerja positif guru tersertifikasi disebabkan oleh peningkatan kesejahteraan guru, peningkatan motivasi kerja guru dan peningkatan tanggung jawab. Sedangkan faktor penghambat guru tersertifikasi yang belum dapat melaksanakan kinerja dengan baik adalah faktor kompetensi, kurangnya pembinaan guru serta terbatasnya sarana prasarana.
\end{abstract}

Kata Kunci : Sertifikasi Guru, Profesionalisme Guru, Kaltim.

\begin{abstract}
This study aims to describe the relationship of teacher certification with teacher professionalism in East Kalimantan (Samarinda City, Balikpapan City, Kutai Kartanegara Regency and Kutai Timur Regency). This type of research uses qualitative research through explanatory methods. Data collection techniques are carried out through FGDs and interviews with the Department of Education, School Superintendents, Principals and Teachers were also supported by literature studies relating to teacher certification policies. The results showed that the professionalism of certified teachers in East Kalimantan was generally quite good. The teachers had met the set work standards, but the standards performance that is fulfilled by teachers tends to be only fulfilling obligations and is not yet an embodiment of a professional work culture. The factors driving the emergence of certified teacher's positive performance are caused by increased teacher welfare, increased teacher work motivation and increased responsibility. While the inhibiting factors for certified teachers who have not been able to perform well are competency, lack of teacher guidance and limited infrastructure.
\end{abstract}

Keywords : Teacher Certification, Teacher's Professionalism, East Kalimantan. 
Pelaksanaan Kebijakan Sertifikasi Guru Dalam Meningkatkan Profesionalisme Guru di Kalimantan Timur (Studi Kasus di Kota Samarinda, Kota Balikpapan, Kabupaten Kutai Kartanegara dan Kabupaten Kutai Timur)

Ratih Fenty Anggriani Bintoro, Yuli Fitrianto

\section{PENDAHULUAN}

Hakekat pembangunan nasional adalah pembangunan manusia Indonesia seutuhnya dan pembangunan masyarakat seluruhnya. Keberhasilan pembangunan tidak lagi diukur dari segi ekonomi tapi seberapa besar pembangunan itu bisa meningkatkan kualitas sumberdaya manusia (SDM). Karena itu investasi pada aspek pengembangan SDM sebagai modal dasar pembangunan sangat dibutuhkan. Pada saat ini potensi SDM Indonesia sebagai salah satu sumberdaya pembangunan lebih ditekankan pada aspek kuantitasnya sedangkan aspek kualitas masih terus dikembangkan, sehingga belum dapat diberdayakan secara optimal sebagai sumber daya pembangunan. Salah satu upaya untuk meningkatkan kualitas SDM dapat dilakukan dengan meningkatkan kualitas pendidikan karena dengan pendidikan yang berkualitas akan tercipta SDM yang berkualitas pula, yang pada akhirnya dapat mendukung terwujudnya target pembangunan nasional.

Syarat mutlak untuk menciptakan sistem dan praktik pendidikan yang bermutu/berkualitas adalah guru yang profesional, karena guru adalah ujung tombak dalam peningkatan kualitas layanan dan hasil pendidikan, khususnya dalam membangun dan meningkatkan kualitas sumber daya manusia (SDM) melalui pendidikan formal. Guru adalah sebuah profesi yang sangat strategis dalam pembentukan dan pemberdayaan anak-anak penerus bangsa. Oleh karena itu, pemberdayaan dan peningkatan kualitas guru sebagai tenaga pendidik merupakan keharusan yang memerlukan penanganan serius. Untuk itu pemerintah telah menerbitkan UU RI Nomor 20 Tahun 2003 tentang Sistem Pendidikan Nasional (Sisdiknas) dan UU RI Nomor 14 Tahun 2005 tentang Guru dan Dosen (UUGD), UUGD pasal 8 menyatakan bahwa seorang guru wajib memiliki kualifikasi akademik, kompetensi, sertifikat pendidik, sehat jasmani dan rohani, serta memiliki kemampuan untuk mewujudkan tujuan pendidikan nasional. Sedangkan pada pasal Pasal 11, ayat (1) menyebutkan bahwa sertifikat pendidik sebagaimana dalam pasal 8 diberikan kepada guru yang telah memenuhi persyaratan. Turunan dari UUGD yaitu PP Nomor 74 Tahun 2008 tentang Guru, pasal 4 ayat (1) menyatakan bahwa sertifikat pendidik didapat dari program pendidikan profesi oleh perguruan tinggi yang memiliki program pengadaan tenaga kependidikan yang terakreditasi, dan di ayat (2) dipersyaratkan kualifikasi akademik minimal adalah S1 atau D-IV.

Berdasarkan Data Pokok Pendidikan (Dapodik) diketahui jumlah guru, kepala sekolah dan pengawas di Kaltim yang belum bersertifikat pendidik per tahun 2017 (semester I) sebanyak 3.386 orang atau $53 \%$ dari total jumlah keseluruhan. Hal ini menyebabkan peserta didik belum memperoleh jaminan untuk mendapatkan pendidikan yang bermutu dari guru yang profesional yang dibuktikan dengan memiliki sertifikat pendidik (LHP BPK RI,2017:3).

Suwardi (2012, 7-9), telah mengidentifikasi bahwa pelaksanaan sertifikasi guru setidaknya telah dapat memberikan dampak positif bagi guru, antara lain untuk: 1) perbaikan kualitas guru; 2) perlindungan terhadap profesi guru; 3) perbaikan kesejahteraan guru; 4) mendorong minat kalangan muda untuk mengabdi sebagai guru; 5) meningkatkan administrasi pendidikan; 6) meningkatkan motivasi guru untuk membuat karya tulis ilmiah. Namun Badruzzaman (2016:8) menemukan bahwa guru sertifikasi masih dominan memanfaatkan tunjangan sertifikasinya untuk pemenuhan kebutuhan dasar dibandingkan untuk peningkatan kualitas profesi.

Berangkat dari temuan di atas, maka menarik untuk melihat bagaimana gambaran pelaksanaan sertifikasi guru dalam upaya untuk meningkatkan profesionalisme guru di Kaltim.

\section{TINJAUAN PUSTAKA}

\section{Evaluasi Kebijakan}


Evaluasi kebijakan dapat dikatakan sebagai kegiatan yang menyangkut estimasi atau penilaian kebijakan yang menyangkut substansi, implementasi dan dampak. Dalam hal ini, evaluasi kebijakan dipandang sebagai suatu kegiatan fungsional. Artinya, evaluasi kebijakan tidak hanya dilakukan pada tahap akhir saja, melainkan dilakukan dalam seluruh proses kebijakan. Menurut Anderson dalam Winarno (2012:230), secara umum evaluasi kebijakan yang mencakup substansi, implementasi dan dampak pelaksanaan kebijakan tersebut.

Menurut Lester dan Stewart dalam Winarno (2012:229), evaluasi kebijakan dapat dibedakan ke dalam dua tugas yang berbeda, tugas pertama adalah untuk menentukan konsekuensi-konsekuensi yang ditimbulkan oleh suatu kebijakan dengan cara menggambarkan dampaknya. Sedangkan tugas kedua adalah untuk menilai keberhasilan atau kegagalan dari suatu kebijakan berdasarkan standar atau kriteria yang telah ditetapkan sebelumnya. Tugas pertama merujuk pada usaha untuk melihat apakah program kebijakan publik mencapai tujuan atau dampak yang diinginkan atau tidak. Tugas kedua dalam evaluasi kebijakan pada dasarnya berkait erat dengan tugas pertama. Dimana setelah kita mengetahui konsekuensi-konsekuensi kebijakan melalui penggambaran dampak kebijakan publik, maka kita dapat mengetahui apakah program kebijakan yang dijalankan sesuai atau tidak dengan dampak yang diinginkan.

\section{Sertifikasi Guru}

UU RI No 14 Tahun 2005 tentang Guru dan Dosen, menyebutkan sertifikat pendidik diberikan kepada guru yang telah memenuhi persyaratan kualifikasi akademik dan kompetensi sebagai agen pembelajaran. Sertifikat pendidik diberikan kepada seseorang yang telah menyelesaikan program pendidikan profesi pendidik dan lulus uji sertifikasi pendidik. Dalam hal ini, ujian sertifikasi pendidik dimaksudkan sebagai kontrol mutu hasil pendidikan, sehingga seseorang yang dinyatakan lulus dalam ujian sertifikasi pendidik diyakini mampu melaksanakan tugas mendidik, mengajar, melatih, membimbing, dan menilai hasil belajar peserta didik. Namun saat ini, mengacu pada Permendiknas Nomor 18 tahun 2007 tentang Sertifikasi agi Guru dalam Jabatan disebutkan bahwa sertifikasi bagi guru dalam jabatan dilaksanakan melalui uji kompetensi dalam bentuk penilaian portofolio alias penilaian kumpulan dokumen yang mencerminkan kompetensi guru.

Uji kompetensi ini dilakukan untuk memperoleh sertifikat pendidik dan dilakukan dalam bentuk penilaian terhadap kumpulan dokumen yang mencerminkan kompetensi guru. Komponen-komponen portofolio tersebut mencakup a) Kualifikasi akademik, b) Pendidikan dan pelatihan dalam rangka pengembangan dan peningkatan kompetensi, c) Pengalaman mengajar, d) Perencanaan dan pelaksanaan pembelajaran, e) Penilaian dari atasan dan pengawas, f) Prestasi akademik, g) Karya pengembangan profesi, h) Keikutsertaan dalam Forum Ilmiah, i) Pengalaman organisasi di bidang pendidikan dan sosial, j) Penghargaan yang relevan dengan bidang pendidikan.

\section{Guru Profesional}

Guru adalah pendidik profesional dengan tugas utama mendidik, mengajar, membimbing, mengarahkan, melatih, menilai, dan mengevaluasi peserta didik pada pendidikan anak usia dini jalur pendidikan formal, pendidikan dasar, dan pendidikan menengah (UU No. 14 tahun 2005). Pekerjaan profesional yang disandang oleh guru dalam melaksanakan tugasnya, sangat dipengaruhi oleh dua faktor besar yaitu faktor internal yang meliputi minat dan bakat dan faktor eksternal yaitu berkaitan dengan lingkungan sekitar, sarana prasarana, serta berbagai latihan yang dilakukan guru.

Keputusan Menteri Pendidikan No. 16 Tahun 2007 menekankan 4 (empat) kompetensi guru yang harus dimiliki untuk dapat meningkatkan mutu guru di Indonesia sehingga memenuhi standar profesional guru. Untuk menjadi profesional seorang guru dituntut untuk 
memiliki 5 (lima) hal sebagai berikut : (1) Guru mempunyai komitmen pada siswa dan proses belajarnya, (2) Guru menguasai secara mendalam bahan/mata pelajaran yang diajarkannya serta cara mengajarnya kepada siswa, (3) Guru bertanggung jawab memantau hasil belajar siswa melalui berbagai cara evaluasi, (4) Guru mampu berfikir sistematis tentang apa yang dilakukannya dan belajar dari pengalamannya, (5) Guru seyogyanya merupakan bagian dari masyarakat belajar dalam lingkungan profesinya (organisasi profesi).

Lebih lanjut, Hidayanto (2011) menyebutkan jika seseorang menerima pekerjaan guru sebagai profesi berarti ia secara langsung dan tegas menerima kepercayaan itu dari pemerintah dan masyarakat. Oleh karena itu, di samping ia harus memiliki syarat sebagai manusia dewasa, ia juga harus memenuhi persyaratan lain yang dapat dikelompokkan sebagai persyaratan pribadi dan persyaratan jabatan.

1. Persyaratan Pribadi

Persyaratan pribadi mencakup: (1) berbudi luhur dan berbadan sehat, (2) berkecerdasan cukup, (3) bertemperamen tenang, (4) beremosi stabil, (5) manusia masyarakat. Persyaratan pribadi ini sejalan dengan upaya menghasilkan guru berkarakter HADITS. Untuk menghasilkan guru profesional berkarakter HADITS atau bercirikan sesuai konsep para ahli yang lain, diperlukan syarat, yakni ia harus cerdas akal, cerdas hati, dan cerdas rokhani. Cerdas akal identik dengan KI (Kecerdasan Intelektual), cerdas hati identik dengan KE (Kecerdasan Emosional) dan cerdas rokhani identik dengan KS (Kecerdasan Spiritual).

Semua guru hampir dapat dipastikan telah memiliki KI. Akan tetapi apakah semuanya telah memiliki KE dan KS merupakan pertanyaan penting. Jika sebagian, sebagian besar, maupun sebagian kecil belum memilikinya maka pelatihan ini merupakan salah satu upaya diantara upaya-upaya lain agar guru memiliki dan mengimplementasikan KE dan KS bersamaan dengan KI.

2. Persyaratan Jabatan

Adapun persyaratan jabatan mencakup (1) memiliki pengetahuan tentang manusia dan masyarakat, (2) memiliki pengetahuan dasar fundamental, (3) memiliki pengetahuan keahlian bidang studi, (4) memiliki pengetahuan kepempimpinan pendidikan, (5) memiliki filsafat pendidikan yang konsisten.

\section{METODE}

Penelitian ini menggunakan metode kualitatif dengan pendekatan deskriptif. Mengingat keterbatasan waktu, tenaga dan biaya, maka perlu ada pembatasan jangkauan wilayah penelitian. Penelitian ini hanya dilakukan di 4 (empat) Kabupaten/Kota di Provinsi Kalimantan Timur yang dipilih dengan menggunakan metode cluster sampling. Klaster utara yaitu di Kabupaten Kutai Kartanegara, klaster timur adalah Kabupaten Kutai Timur, klaster tengah adalah Kota Samarinda, dan klaster selatan adalah Kota Balikpapan.

Pengumpulan data dilakukan dengan dua cara yaitu 1) penjaringan data primer melalui Focus Group Discussion (FGD) dan wawancara mendalam (indepth- interview) kepada beberapa key informants seperti Kepala Dinas Pendidikan, Pengawas Sekolah, Kepala Sekolah dan Guru 2) Penjaringan data sekunder untuk menunjang analisis yang bersumber dari buku, jurnal, hasil penelitian, proceeding serta informasi lainnya yang menunjang penelitian ini seperti koran, majalah maupun website.

Fokus Penelitian adalah melakukan pemetaan terhadap profesionalisme guru tersertifikasi pada jenjang pendidikan SD, SMP, SMK dan SMK serta mengidentifikasi berbagai kendala yang dihadapi dalam meningkatkan profesionalisme guru. 


\section{HASIL DAN PEMBAHASAN}

\section{Profesionalisme Guru Tersertifikasi Di Kaltim}

Berdasarkan hasil wawancara dan FGD yang dilakukan di 4 Kabupaten/Kota yaitu Kota Samarinda, Kota Balikpapan, Kab Kutai Kartanegara dan Kabupaten Kutai Timur diperoleh beberapa temuan tentang keprofesionalan guru di Kaltim sebagai berikut :

\section{a. Kota Samarinda}

Berdasarkan pendapat Bapak Djoko Imadudin (Kasi Tendiknas Disdik Kota Balikpapan) bahwa dalam perkembangannya, sertifikasi kurang membawa dampak terhadap mutu dan kinerja guru (di Kaltim). Sertifikasi tidak serta merta meningkatkan mutu guru. Bila dikaitkan dengan hasil perolehan nilai siswa dalam UN, Kaltim masih tertinggal cukup jauh dibandingkan dengan Provinsi lainnya. Kinerja guru belum mengarah pada tugas-tugas profesional. Pada umumnya mereka cenderung sekadar memenuhi tugas rutin mengajar, sesuai aturan mengajar 24 jam, dan mulai kehilangan roh sebagai guru. Hal ini diduga akibat dari kebijakan pemerintah yang hanya mengejar linearitas. Maka di harapkan adanya keberanian pemerintah, baik Provinsi/Kota/Kabupaten untuk menata distribusi guru. selama ini juga belum pernah ada pelatihan-pelatihan bagi guru yang mengarah pada perubahan mindset guru, perubahan karakter/kepribadian seorang guru, serta perubahan kompetensi sosial.

Pendapat yang sama juga disampaikan oleh Bapak Basrani (pengawas TK/SD) bahwa memang pada kenyataannya masih terdapat cukup banyak guru yang hanya bekerja untuk menggugurkan kewajibannya dan tidak mau melakukan tugas-tugas sebagaimana guru profesional.

Berdasarkan dua pendapat di atas nampak bahwa harapan untuk mendapatkan guru profesional pasca diberikan pelatihan sertifikasi dan dibayarkan tunjangan sertifikasi tidaklah mudah, masih diperlukan pembinaan dan pengawasan yang terus-menerus dan disertai dengan kelengkapan sarana belajar mengajar yang cukup.

Ketika dikonfirmasi perihal pengaruh sertifikasi terhadap peningkatan profesionalisme, salah satu informan guru MAN 1 Samarinda menyatakan bahwa tunjangan sertifikasi memang sangat berpengaruh terhadap kesejahteraan guru dan kinerja. Namun yang perlu dipertanyakan adalah bagaimana pelaksanaan penilaian kinerja guru profesional dijalankan

"Pertanyaannya bagaimana penilaian kinerja guru dijalankan? Penilaian terhadap guru yang profesional itu seperti apa? yang pasti di sekolah saya, pada awal bulan para guru mengumpulkan RPP, termasuk penilaian, dan absen siswa, sifatnya wajib dikumpulkan. Jika hal ini dijalankan maka profesionalisme guru sendiri akan meningkat. Terkait dengan waktu mengajar. Kita dituntut untuk menilai siswa, tapi waktunya habis untuk mengejar waktu mengajar 24 jam. Perlu dilakukan evaluasi secara berjenjang. Peningkatan kapasitas bagi guru di MAN memang sangat kurang. Untuk penggunaan tunjangan sertifikasi, pada kenyataannya kurang beli buku, tapi mungkin dia beli laptop/hp yang bisa menyimpan file ribuan e-book sebagai pengganti pembelian buku".

Sementara guru yang lain menyampaikan bahwa dampak sertifikasi para guru telah mampu bekerja sesuai dengan bidang ilmunya. Pembagian tugas semakin jelas. Namun juga terjadi kendala bahwa terdapat beberapa mata pelajaraan yang tidak dapat mencakup 24 jam dengan alasan jumlah jam kurang rombel sangat terbatas. sehingga diperlukan distribusi guru yang baik dan pemerintah membantu mencarikan jalan keluar bagi buru yang mengalami kendala ini. Hal 
Pelaksanaan Kebijakan Sertifikasi Guru Dalam Meningkatkan Profesionalisme Guru di Kalimantan Timur (Studi Kasus di Kota Samarinda, Kota Balikpapan, Kabupaten Kutai Kartanegara dan Kabupaten Kutai Timur)

Ratih Fenty Anggriani Bintoro, Yuli Fitrianto

lain yang dipandang perlu bahwa keprofesionalan tanpa didukung dengan sarana dan fasilitas pembelajaran yang memadai diyakini akan kurang efektif hasilnya.

Berdasarkan hasil penelitian yang digali melalaui FGD, wawancara dan observasi yang telah diuraikan diatas terhadap profesionalisme guru di Samarinda dapat disimpulkan cukup baik. bahwa dampak dari tunjangan sertifikasi guru telah mampu meningkatkan kinerja guru. Guru telah memenuhi standar kerja yang ditetapkan, sebagian besar guru juga menyusun perangkat pembelajaran seperti RPP, Silabus dan instrumen lainya. Hal yang perlu ditingkatkan adalah komitmen dan budaya kerja profesional. Tugas pemerintah di era otonomi daerah adalah meningkatkan Sumber Daya Manusia (SDM) di daerahnya melalui peningkatan mutu pendidikan, sehingga peningkatan mutu guru harus diperhatikan. berdasarkan hasil FGD juga diperoleh kesan belum ada sinkronisasi antara harapan pemerintah dan keinginan guru. Pemerintah melalui Dinas Pendidikan berkewajiban membina dan memonitor kinerja guru. Di lain pihak para guru mengeluh perlunya diberikan pembinaan yang layak bagi peningkatan mutu guru.

\section{b. Kota Balikpapan}

Kota Balikpapan dipandang sebagai salah satu tolok ukur/acuan pendidikan di Kalimantan Timur. Kota Balikpapan memiliki sekolah-sekolah unggul yang menjadi rujukan pendidikan di Kaltim. Hal ini tidak lepas dari sistem pembinaan yang dilakukan oleh Pemerinah Kota Balikpapan. Pemberian tunjangan sertifikasi bagi guru di Kota Balikpapan merupakan salah satu penghargaan yang diharapkan dapat meningkatkan kinerja guru, sebagaimana disampaikan oleh Ketua Dewan Pendidikan Kota Balikpapan, Bapak Subianto sebagai berikut :

Sertifikasi yang kompensasinya adalah tunjangan profesi tidak bisa dikaitkan dengan peningkatan kompetensi guru. Sertifikasi hanya dapat dipandang sebagai kompensasi atas jasa guru selama ini, yang selama ini dininabobokan dengan predikat "pahlawan tanpa tanda jasa". Salah kaprah bila dikaitkan bahwa sertifikasi merupakan tolak ukur peningkatan mutu pendidikan. Dengan tunjangan sertifikasi, guru dapat lebih fokus untuk meningkatkan mutu pembelajaran dikaitkan dengan 4 (empat) kompetensi yaitu kompetensi pedagogik, kompetensi professional, kompetensi sosial dan kompetensi kepribadian. Bila ingin kualitas guru meningkat, tidak ada cara lain selain meningkatkan kuota diklat untuk peningkatan kualitas guru dan secara pribadi guru juga harus proaktif dalam meningkatkan kompetensinya.

Sementara itu, pengawas SMP, Bapak Mujiono menyatakan bahwa:

Pengaruh sertifikasi efeknya belakangan. Yang paling terlihat dan terasa adalah peningkatan kesejahteraan dan pada akhirnya hal tersebut membuat guru menjadi lebih fokus dalam melaksanakan tugasnya. Bila pengawas sekolah mengadakan supervisi ke lapangan, guru sudah siap perangkatnya baik dalam hal perencanaan, pelaksanaan dan evaluasi karena sudah memiliki laptop masing masing yang dibeli dengan menggunakan dana tunjangan sertifikasi.

Masih menurut Mujiono, yang perlu difikirkan adalah bagaimana mempertahankan budaya kerja guru di Kota Balikpapan yang sudah dipandang mulai membaik. Hal yang sama sebagaimana pengawas Bapak Dirson, pengawas SMK yang menyatakan :

Bahwa di kota Balikpapan, pelaksanaan pembelajaran sudah cukup baik. Setiap satu semester diadakan validasi tentang kinerja guru dalam pembuatan perangkat pelaksanaan pembelajaran. Sertifikasi berpengaruh terhadap kinerja namun juga jangan menjadi tuntutan untuk peningkatan kinerja. Tunjangan sertifikasi merupakan motivasi untuk peningkatan kinerja. 
Pelaksanaan Kebijakan Sertifikasi Guru Dalam Meningkatkan Profesionalisme Guru di Kalimantan Timur (Studi Kasus di Kota Samarinda, Kota Balikpapan, Kabupaten Kutai Kartanegara dan Kabupaten Kutai Timur)

Ratih Fenty Anggriani Bintoro, Yuli Fitrianto

Ditambahkan oleh salah seorang guru, Ibu Rina Noviana yang menyatakan bahwa :

Secara pribadi, sertifikasi berdampak terhadap kinerja. Guru dapat sekolah S2 dengan biaya dari tunjangan sertifikasi. Terkait motivasi guru, lingkungan sangat mempengaruhi motivasi dan peran kepsek penting. Sertifikasi memiliki pengaruh yang signifikan dalam hal peningkatan kesejahteraan guru yang pada akhirnya berpengaruh pada peningkatan motivasi dan disiplin guru dalam mengajar. Sertifikasi guru juga berpengaruh signifikan terhadap kualitas pendidikan di Kota Balikpapan, hal tersebut dapat dibuktikan dengan meningkatnya persentasi kelulusan pada semua jenjang pendidikan.

Berdasarkan hasil FGD dan wawancara di atas dapat disimpulkan bahwa di Kota Balikpapan profesionalime guru dirasa meningkat pasca diberikan tunjangan sertifikasi.

\section{c. Kabupaten Kutai Kartanegara}

Kabupaten Kutai Kartanegara merupakan salah satu kabupaten di Kalimantan Timur yang memiliki tenaga guru paling banyak. Distribusi guru di Kabupaten Kutai Kartanegara juga memiliki keunikan tersendiri, karena daerahnya yang cukup luas dan memiliki keragaman yang tinggi.

Berdasarkan hasil FGD yang dihadiri oleh Dinas Pendidikan, guru dan pengawas di Kabupaten Kutai Kartanegara didapatkan hasil bahwa sangat diperlukan adanya peningkatan pada aspek kepribadian guru sehingga mampu mengubah paradigma tentang tugas dan fungsi guru. Tunjangan profesi semestinya dapat dipandang sebagai upaya peningkatan kesejahteraan guru agar guru dapat bekerja secara profesional, sehingga tunjangan profesi melekat pada keprofesionalan dalam bekerja. Semestinya pola pikir yang masih mengejar perubahan penghasilan saja dan tidak mengimbanginya dengan kinerja harus dibina secara khusus.

Selanjutnya Kepala Sekolah SMP Negeri 4 Agus Suparmanto menyampaikan bahwa Sertifikasi guru belum berdampak luas kepada guru, terutama dalam segi kepribadian dan komitmen. Para guru pada umumnya masih terikat dengan peraturan dan Standar Operasional Prosedur (SOP), sehingga perlu dipikirkan solusinya. Meskipun ada penilaian kinerja $(P K G)$ tapi ada toleransi penilaian. Disarankan pula bahwa untuk meningkatkan kinerja guru harus ada ukuran yang jelas baik segi kriteria kinerja maupun outcome-nya. Kalau PKG dilakukan dengan benar maka akan meningkatkan kualitas. Harus dikaitkan dengan kenaikan pangkat atau insentif, PKG harus dientry oleh pengawas, hasilnya disetujui oleh Kepsek. Lebih lanjut disampaikan oleh salah satu Kepsek MTSn bahwa pada dasarnya sertifikasi dapat meningkatkan kinerja tapi tidak signifikan, ada perubahan tapi kecil saja.

Beberapa permasalahan yang dominan disampaikan pada saat FGD dan wawancara sehubungan syarat kompetensi sertifikasi adalah perbandingan kualitas kinerja antara guru sertifikasi yang sudah 50 tahun keatas; sulitnya pemenuhan ketentuan 24 jam tatap muka mengingat pada beberapa sekolah memiliki keterbatasan jumlah jam pelajaran dan jumlah kelas; ketidakseimbangan jumlah guru pada mata pelajaran tertentu di beberapa sekolah menyebabkan guru harus mengajar disekolah lain; penilaian kinerja guru tidak diimbangi dengan penyiapan SDM sebagai tenaga asesor; proses pelatihan yang bisa dipandang 'instan' sehingga tidak mampu menciptakan profesionalisme guru; pembayaran sertifikasi yang tidak diberikan kepada guru yang belum memenuhi ketentuan.

Sehubungan tunjangan sertifikasi terdapat informan yang menyarankan perlunya ketentuan tambahan agar pembayaran tunjangan sertifikasi dibuat persentasi sesuai capaian kinerja 
Pelaksanaan Kebijakan Sertifikasi Guru Dalam Meningkatkan Profesionalisme Guru di Kalimantan Timur (Studi Kasus di Kota Samarinda, Kota Balikpapan, Kabupaten Kutai Kartanegara dan Kabupaten Kutai Timur)

Ratih Fenty Anggriani Bintoro, Yuli Fitrianto

sehingga setiap guru dipastikan menerima tunjangan meskipun pemenuhan jam mengajar masih kurang

Dari hasil FGD dan wawancara tersebut, nampaknya para stakeholder kurang yakin adanya dampak yang signifikan antara sertifikasi guru dan profesionalisme guru namun demikian dari hasil tersebut dapat disimpulkan bahwa ada dampak positif terhadap peningkatkan profesionalisme guru.

\section{d. Kabupaten Kutai Timur}

Kutai Timur merupakan salah satu kabupaten di Kaltim yang secara konsisten menerapkan kurikulum 2013 secara menyeluruh. Untuk dapat melaksanakan kurikulum 2013 secara penuh tentunya memerlukan tenaga guru yang berkompetensi tinggi. Berdasarkan hasil wawancara dan FGD di Kabupetan Kutai Timur, diperoleh informasi bahwa secara umum kinerja guru di Kabupaten Kutai Timur sudah baik. Dinas Pendidikan Kabupaten Kutai Timur sudah menunjukkan kinerja yang baik dalam pembinaan kinerja guru. Dampak pembinaan guru yang baik saat ini kinerja guru di Kutim dapat dikategorikan sangat baik. Hal ini disampaikan oleh Kabid Pendidikan Dasar Disdik Kab. Kutai Timur sebagai berikut:

Dampak dari sertifikasi tersebut sangat terlihat hingga saat ini adanya perubahan kualitas para guru baik secara manajerial maupun kompetensinya, karena persyaratan untuk sertifikasi harus memenuhi beberapa syarat.

Hal tersebut dikuatkan juga oleh guru dari SDN 003 Sangatta dan SMP 1 Bengalon yang menyatakan bahwa sertifikasi berpengaruh besar terutama bagi kesejahteraan guru selain itu dengan adanya sertifikasi guru menjadi lebih termotivasi untuk mengajar, disiplin lebih meningkat

Terkait kendala dalam sertifikasi, peserta FGD menyimpulkan beberapa hal yang dirasa menjadi kendala seperti 1) Pemenuhan ketentuan 24 jam mengajar, 2) Linearitas latar belakang pendidikan guru dengan mata pelajaran yang diampu, dan 3) Kurangnya kuota diklat untuk peningkatan kompetensi guru.

Berdasarkan hasil wawancara dan FGD tentang keprofesionalan guru pasca diberikan tunjangan sertifikasi di Kabupaten Kutai Timur dapat disimpulkan bahwa sertifikasi berpengaruh positif dalam meningkatkan profesionalisme guru di Kabupaten Kutai Timur.

Guru mempunyai peran yang sangat strategis dalam upaya mewujudkan tujuan pembangunan nasional, khususnya dibidang pendidikan, sehingga perlu dikembangkan sebagai tenaga profesi yang bermartabat dan profesional. Namun dalam perwujudannya, tanggung jawab perlu ditekankan dan dikedepankan, karena pada saat ini banyak lulusan pendidikan yang cerdas dan terampil tetapi tidak memiliki tanggung jawab dalam mengamalkan ilmu dan keterampilan yang dimilikinya. Dalam kerangka inilah dirasakan perlunya standar kompetensi dan sertifikasi guru, agar kita memiliki guru profesional yang memenuhi standar dan lisensi sesuai dengan kebutuhan.

Sertifikasi adalah proses pemberian sertifikat pendidik untuk guru. Hal ini berarti bahwa sertifikasi guru dapat pandang sebagai suatu proses pemberian pengakuan bahwa seseorang telah memiliki kompetensi untuk melaksanakan pelayanan pendidikan pada satuan pendidikan tertentu setelah uji kompetensi yang diselenggarakan oleh lembaga sertifikasi (UU RI nomor 14 tahun 2005). Sertifikasi guru merupakan amanat UU RI Nomor 20 Tahun 2003 tentang Sisdiknas, pada Pasal 61 menyatakan bahwa sertifikat dapat berbentuk ijazah dan sertifikat kompetensi. Mulyasa (2008: 221-225), mengungkapkan bahwa sertifikasi bertujuan untuk melindungi profesi pendidik dan tenaga kependidikan, melindungi masyarakat dari praktikpraktik yang tidak kompeten, membantu dan melindungi lembaga penyelenggara pendidikan untuk melakukan seleksi terhadap pelamar yang kompeten, membangun citra masyarakat 
terhadap profesi pendidik dan tenaga kependidikan, memberikan solusi dalam rangka meningkatkan mutu pendidikan dan tenaga kependidikan.

Guru tersertifikasi dituntut memiliki kinerja yang mampu memberikan dan merealisasikan harapan dan keinginan semua pihak terutama masyarakat pengguna pendidikan yang telah mempercayai sekolah dan guru dalam membina anak didik. Dalam meraih mutu pendidikan yang baik sangat dipengaruhi oleh kinerja guru dalam melaksanakan tugasnya sehingga kinerja guru menjadi tuntutan penting untuk mencapai keberhasilan pendidikan. Secara umum mutu pendidikan yang baik menjadi tolok ukur bagi keberhasilan kinerja yang ditunjukkan guru.

\section{Faktor Pendorong dan Penghambat Kinerja Guru Tersertifikasi}

Berdasarkan hasil penelitian yang digali melalui FGD maupun wawancara di 4 (empat) kabupaten/kota memberikan gambaran yang cukup seragam terkait aktor pendorong dan penghambat kinerja guru tersertifikasi di Kalimantan Timur bila dikaitkan dengan profesionalitas. Bila dikelompokkan berdasarkan permasalahannya faktor-faktor pendorong dan penghambat kinerja guru tersertifikasi disebabkan oleh :

\section{a. Faktor Pendorong}

\section{1) Peningkatan Kesejahteraan Guru.}

Berdasarkan informasi yang di peroleh dari responden di 4 (empat) Kabupaten/kota bahwa dampak peningkatan kesejahteraan guru maka diperoleh peningkatan kinerja guru yang lebih baik. Hasil wawancara di 4 (empat) Kabupaten/Kota memberi pernyataan yang sama bahwa peningkatan kesejahteraan guru juga berdampak positif bagi guru untuk dapat memenuhi kebutuhan sarana mengajar seperti Laptop, LCD, buku dll. Peningkatan kesejahteraan menjadikan guru lebih fokus mengerjakan tugas-tugas keprofesionalannya tanpa banyak diganggu oleh pekerjaan sampingan untuk memenuhi kebutuhan lainnya.

\section{2) Peningkatan Motivasi Kerja Guru.}

Motivasi merupakan keinginan yang terdapat pada individu yang merangsang untuk melakukan tindakan-tindakan atau sesuatu yang menjadi dasar atau alasan seseorang berperilaku, sehingga motivasi kerja diartikan sebagai keinginan atau kebutuhan yang melatarbelakangi seseorang sehingga ia terdorong untuk bekerja. Tunjangan sertifikasi memiliki makna tersendiri bagi peningkatan motivasi guru untuk bekerja lebih baik.

\section{3) Peningkatan Tanggung Jawab}

Sertifikat yang diberikan kepada para guru tersertifikasi mengandung tanggung jawab profesi yang harus dijalankan guru. Tanggung jawab itu juga muncul pada sebagian besar guru tersertifikasi, terutama pada guru yang berusia muda, hal ini terjadi disemua daerah lokasi penelitian. Upaya yang dilakukan oleh pemerintah kabupaten/kota dalam meningkatkan tanggung jawab guru pada pekerjaan profesionalnya, maka diwajibkan guru untuk melakukan laporan rutin baik dari produk kerjanya maupun aktivitas kinerja kesehariannya. Laporan tersebut dimonitor dan dievaluasi oleh pengawas setempat dan menjadi dasar untuk penilaian kinerja guru.

\section{b. Faktor Penghambat}

\section{1) Faktor Kompetensi}

Perkembangan global menuntut semua pihak dapat mengikuti irama kebutuhan di era global. Di era global pertumbuhan IPTEK begitu pesat, tak terkecuali untuk bidang pendidikan. Saat ini pemanfaatan teknologi dalam pembelajaran tidak bisa dihindari, sehingga guru harus dapat memanfaatkan teknologi dalam pendidikan. Kurikulum 2013 juga tidak bisa menghindarkan guru dari aktivitas di laboratorium, sehingga kompetensi dalam bidang-bidang eksperimen dan perkembangan pengetahuan harus diikuti guru. Realitanya masih cukup 
banyak guru yang belum memanfaatkan teknologi dalam pembelajaran, dan disayangkan guru IPA tidak pernah menyentuh laboratorium, sehingga kinerja profesionalnya belum dapat dioptimalkan.

\section{2) Pembinaan Guru}

Peningkatan kinerja guru merupakan harapan pemerintah yang proses panjang yang memerlukan proses panjang untuk melaksanakan. Dikatakan proses panjang karena memerlukan banyak pihak yang terlibat. Kepala sekolah sebagai unsur terdekat yang harus senantiasa meningkatkan kinerja guru. Pengawas pendidikan bertugas untuk mengawasi, membina dan mengavaluasi kinerja guru, sedangkan Dinas Pendididikan harus memiliki program-program unggulan untuk meningkatkan kinerja guru dalam mencapai tujuan pemerintah. Di beberapa Kabupaten/Kota sudah nampak hasil pembinaan guru namun dibeberapa tempat belum menunjukkan pembinaan yang cukup baik, sehingga diperlukan sinergi yang baik dalam melakukan pembinaan pada guru.

\section{3) Terbatasnya Sarana Prasarana.}

Sarana dan fasilitas pendidikan sangat diperlukan untuk melaksanakan proses belajar mengajar. Beberapa guru belum mampu mampu mengimplementasikan kinerja profesionalnya karena keterbatasan sarana dan fasilitas pendidikan. Dalam implementasi Kurikulum 2013 diperlukan sarana dan fasilitas yang memadai agar capaian target kompetensi siswa dapat dipenuhi.

\section{KESIMPULAN}

Profesionalisme guru tersertifikasi di Kalimantan Timur pada umumnya telah cukup baik. Guru telah memenuhi standar kerja yang ditetapkan, namun standar kinerja yang dipenuhi oleh guru cenderung hanya bersifat pemenuhan kewajiban dan belum merupakan perwujudan dari budaya kerja profesional mengingat terdapat indikasi belum terwujudnya budaya kerja profesional seperti keluhan guru mengenai pemenuhan administratif sebagai guru tersertifikasi, penolakan untuk mengaitkan secara langsung tunjangan sertifikasi dengan peningkatan mutu guru dan juga adanya dikotomi guru tersertifikasi antara guru berusia muda dengan guru berusia lebih tua berdasarkan kelompok golongan guru terkait motivasi dan disiplin pasca sertifikasi.

Faktor-faktor pendorong munculnya kinerja positif guru tersertifikasi disebabkan oleh peningkatan kesejahteraan guru, peningkatan motivasi kerja guru dan peningkatan tanggung jawab. Sedangkan faktor penghambat guru tersertifikasi yang belum dapat melaksanakan kinerja dengan baik adalah faktor kompetensi, kurangnya pembinaan guru serta terbatasnya sarana prasarana

\section{REKOMENDASI}

1. Meskipun tingkat profesional dan kinerja guru tersertifikasi telah cukup baik, namun masih diperlukan berbagai upaya peningkatkan komitmen dan budaya kerja profesional bagi guru tersertifikasi, utamanya pada kelompok guru tersertifikasi pada golongan IV ke atas. Peningkatan budaya kerja dapat diciptakan melalui SOP yang disusun dan diimplementasikan di setiap sekolah sesuai amanah UU Nomor 32 Tahun 2013 tentang Standar Layanan Pendidikan. Pembinaan dan keteladanan dari kepala sekolah, pengawas dan Dinas Pendidikan di Kabupaten/Kota diyakini mampu mengembangkan budaya kerja yang baik.

2. Terkait kompetensi guru, arah pengembangan professional guru sebaiknya diawali dengan stimulasi kompetensi sosial dan kepribadian guru tersertifikasi. Jika kebijakan 
hulu kompetensi ini distimulasi maka kompetensi hilir berupa kompetensi pedagogik dan profesional juga akan terstimulasi secara otomatis.

\section{UCAPAN TERIMAKASIH}

Ucapan terima kasih disampaikan kepada informan dalam penelitian ini yang telah meluangkan waktunya untuk memberikan informasi mengenai pelaksanaan kebijakan sertifikasi dikaitkan dengan profesionalisme guru. Semoga hasil penelitian ini dapat menjadi masukan dan gambaran mengenai kendala yang terjadi di lapangan sehingga terdapat perbaikan untuk pelaksanaan di tahun tahun berikutnya.

\section{DAFTAR PUSTAKA}

Badruzzaman. (2016). Dampak Sertifikasi Guru Terhadap Peningkatan Kualitas Pendidikan di Madrasah Aliyah di Kota Palu. Jurnal Al Qalam Volume 22 Nomor 1 Juni 2016.

Badan Pemeriksa Keuangan RI. (2017). Laporan Hasil Pemeriksaan Kinerja Atas Efektivitas Upaya Pemerintah Daerah Dalam Pemenuhan Kebutuhan Guru dan Tenaga Kependidikan Yang Profesional Tahun Anggaran 2015, 2016 dan 2017 Semester I Pada Pemerintah Provinsi Kaltim di Samarinda. Samarinda.

Menteri Pendidikan Nasional. (2007). Keputusan Menteri Pendidikan Nasional Nomor 16 Tahun 2007 tentang Standar Kualifikasi Akademik dan Kompetensi Guru.

Menteri Pendidikan Nasional. (2007). Peraturan Menteri Pendidikan Nasional Nomor 18 Tahun 2007 tentang Sertifikasi Bagi Guru Dalam Jabatan.

Mulyasa, Enco. (2008). Standar Kompetensi dan Sertifikasi Guru. Bandung: PT. Remaja Rosida Karya.

Pemerintah Republik Indonesia. (2003).Undang-Undang Republik Indonesia Nomor 20 Tahun 2003 tentang Sistem Pendidikan Nasional. Penjelasan dalam Tambahan Lembaran Negara Republik Indonesia Nomor 4301. Jakarta: Sekretariat Negara.

Pemerintah Republik Indonesia. (2005). Undang-Undang Republik Indonesia Nomor 14 Tahun 2005 tentang Guru dan Dosen. Lembaran Negara Republik Indonesia Tahun 2005 Nomor 157. Jakarta: Sekretariat Negara.

Pemerintah Republik Indonesia. (2008). Peraturan Pemerintah Nomor 74 Tahun 2008 tentang Guru. Lembaran Negara Republik Indonesia Tahun 2008 Nomor 194. Jakarta: Sekretariat Negara.

Suwardi. (2017). Dampak Sertifikasi Terhadap Peningkatan Kualitas Guru. http://Eprints.Stainsalatiga.ac.id.

Winarno, Budi. (2012). Kebijakan Publik: Teori, Proses dan Studi Kasus. Yogyakarta. CAPS. 